\title{
Review
}

Neonatology

\section{Impaired Pulmonary Vascular Development in Bronchopulmonary Dysplasia}

\author{
Christopher D. Baker Steven H. Abman \\ Pediatric Heart Lung Center, Department of Pediatrics, University of Colorado School of Medicine, \\ Aurora, Colo., USA
}

\section{Key Words}

Bronchopulmonary dysplasia · Premature birth · Vascular development · Chronic lung disease of infancy

\begin{abstract}
Bronchopulmonary dysplasia (BPD), the chronic lung disease associated with preterm birth, results from the disruption of normal pulmonary vascular and alveolar growth. Though BPD was once described as primarily due to postnatal injury from mechanical ventilation and oxygen therapy after preterm birth, it is increasingly appreciated that BPD results from antenatal and perinatal factors that interrupt lung development in infants born at the extremes of prematurity. The lung in BPD consists of a simplified parenchymal architecture that limits gas exchange and leads to increased cardiopulmonary morbidity and mortality. This review outlines recent advances in the understanding of pulmonary vascular development and describes how the disruption of these mechanisms results in BPD. We point to future therapies that may augment postnatal vascular growth to prevent and treat this severe chronic lung disease.
\end{abstract}

(C) 2015 S. Karger AG, Basel
(C) 2015 S. Karger AG, Base

$1661-7800 / 15 / 1074-0344 \$ 39.50 / 0$

\section{Introduction}

Bronchopulmonary dysplasia (BPD) was initially described almost 50 years ago as the chronic lung disease that developed when positive pressure ventilation and oxygen therapy were used to treat 'hyaline membrane disease' or neonatal respiratory distress syndrome in preterm infants [1]. This form of postnatal lung injury was characterized by diffuse inflammation, heterogeneous parenchymal lung injury with areas of marked hyperinflation alternating with fibrosis and atelectasis, airway smooth muscle hypertrophy, edema, and hypertensive vascular remodeling [1-3]. However, advances in both technology and medical management, including routine use of antenatal corticosteroids, artificial surfactant and protective or noninvasive strategies for mechanical ventilation, have led to a dramatic increase in survival of extremely preterm neonates born much earlier in gestation than those originally described by Northway et al. [1] and Jobe [4]. For these infants with 'new BPD', birth occurs during the late canalicular stage of lung development at a time when sufficient thinning of the epithelium has occurred in terminal bronchioles to permit gas exchange and sustain life, well before the terminal airspaces have formed [5-7]. Survival is thus conceivably possible before this stage of maturation only in a setting where extracorporeal oxygenation is provided

\section{KARGER 125}

E-Mail karger@karger.com www.karger.com/neo
Christopher D. Baker, MD

Pediatric Heart Lung Center, Department of Pediatrics University of Colorado School of Medicine

13123 E. 16th Ave, Box B-395, Aurora, CO 80045 (USA)

E-Mail christopher.baker@ucdenver.edu 
and the period has been described as 'the margin of viability' [8]. Recently, the NICHD Neonatal Research Network reported a decline in mortality and pulmonary-related mortality among preterm infants born at 22-28 weeks of gestation [9]. However, the incidence of BPD in this population has been reported to be as high as 68\% [10]. Importantly, in the setting of increased survival, the prevalence of BPD has increased [11,121].

Preterm birth results not only in postnatal respiratory distress but also in arrested development of the distal lung $[4,12]$. Lungs from children with severe BPD have a histological appearance of alveolar simplification, reduced secondary septation and markedly abnormal microvascular growth [13-15]. In this setting of vascular hypoplasia and impaired gas exchange, hypoxia-induced vasoconstriction causes an elevation of pulmonary vascular resistance that leads to vessel remodeling, pulmonary hypertension $(\mathrm{PH})$ and lasting pulmonary vascular disease [16]. Vascular endothelial growth factor (VEGF), a potent angiogenic factor and mediator of nitric oxide (NO) synthesis in endothelial cells, is decreased in the lungs of preterm infants with fatal BPD [17]. In neonatal rodents, inhibition of angiogenesis results in alveolar simplification similar to that seen in preterm infants with BPD [18, 19]. More recently, angiogenic signaling has been shown to promote epithelial differentiation and alveolarization after pneumonectomy in a mouse model [20]. These observations suggest that preterm birth disrupts angiogenesis to cause BPD. A greater understanding of the mechanisms of impaired pulmonary vascular growth will lead to novel therapies for this high-risk population.

\section{Pulmonary Vascular Development: Angiogenesis and Vasculogenesis}

The arrest of growth in the preterm lung results in a decreased capillary density throughout the pulmonary circulation and a smaller cross-sectional area for blood flow with decreased surface area for gas exchange [21]. However, the underlying mechanisms driving pulmonary vascular growth remain the subject of ongoing investigation. In the developing lung, vessel growth occurs by two distinct processes: the direct extension of existing vessels (angiogenesis) and the differentiation of primitive angioblasts and hemangioblasts into de novo vascular structures (vasculogenesis) [22, 23]. During branching morphogenesis of the airways, pulmonary vascular structures form in close proximity, suggesting that the airways may form a template for early vascular development [5].
During the later stages of lung growth, sprouting angiogenesis results in further branching of vascular networks that then coalesce to permit blood flow [5]. As alveolarization continues, double capillary layers fuse to become an endothelial monolayer joined in close approximation to the alveolar epithelium [7, 24]. Further division and septation of alveoli into complex acinar units was once thought to occur postnatally throughout infancy but has recently been shown to continue into adolescence [25].

\section{Vascular Disease in Animal Models of Experimental BPD}

Experimental animal models continue to contribute to our understanding of how vascular growth is impaired in BPD [26-29]. One of the most commonly studied models of BPD involves the exposure of newborn rodent pups to oxidative stress [27, 29-31]. Hyperoxia causes a simplification of lung structure similar to that seen in BPD, with both alveolar simplification and decreased vessel density. The severity of lung injury, including both structural and functional changes, depends on the concentration of inspired oxygen in a dose-dependent manner [32]. After exposure to 7 days of hyperoxia at birth, adult mice (postnatal age 10 months) were recently shown to have sustained airway hypertrophy as well as a significant, albeit mild, reduction in alveolar complexity long after the exposure impaired vascular development and alveolarization [33]. Neonatal hyperoxia-induced lung injury serves as an excellent model for mechanistic studies to better understand how hyperoxia disrupts lung development and for preclinical testing of potential therapies for BPD. The following 'two-hit' models combine postnatal hyperoxia with other antenatal stressors to further study the pathogenesis of BPD: (1) hyperoxia and lipopolysaccharide (LPS) to model perinatal inflammation, such as chorioamnionitis $[34,35],(2)$ hyperoxia and maternal nicotine administration [36] and (3) hyperoxia with intermittent hypoxia, to represent a combined oxidative injury [37-39].

\section{Impaired Angiogenic Signaling in BPD}

The association between VEGF signaling and pulmonary vascular growth has been extensively studied in both large and small animal models [40-42]. Disruption of VEGF signaling impairs angiogenesis and decreases alveolarization to cause experimental BPD [18, 43, 44], whereas treatment with recombinant human VEGF as 
well as VEGF gene therapy promote angiogenesis to prevent $\mathrm{BPD}$ in newborn rats $[19,45]$. Antenatal intra-amniotic treatment with soluble fms-like tyrosine kinase-1 (sFlt-1), an inhibitor of VEGF signaling, results in a BPD phenotype with $\mathrm{PH}$ in newborn rats $[46,47]$. sFlt- 1 is elevated in the amniotic fluid of human mothers with preeclampsia - a strong risk factor for the development of BPD in preterm infants [48-50]. Increased sFlt- 1 in the tracheal aspirates of preterm newborns may be predictive of BPD [51]. In a recent study of preterm infants by Voller et al. [52], the ratio of VEGF to sFlt-1 was decreased in infants with poor postnatal growth but not directly associated with BPD. Lambs with experimental intrauterine growth restriction demonstrate impaired VEGF signaling and develop a BPD phenotype [53]. This finding is consistent with recent clinical observations that the risks of both BPD and death are greater in growth-restricted preterm infants born at $<32$ weeks of gestation compared to extremely preterm infants ( $<28$ weeks) with age-appropriate birth weights [54].

Many other pro- and antiangiogenic mediators also contribute to the pathogenesis of BPD [55]. The potent vasoconstrictor ET-1 (endothelin-1) impairs angiogenesis via activation of intracellular Rho-kinase and decreased PPAR- $\gamma$ signaling $[56,57]$. Nebulized rosiglitazone, a PPAR- $\gamma$ agonist, reduces the severity of hyperoxia-induced lung injury in rat pups [58]. The antiangiogenic mediator endostatin and the ratio of endostatin to angiopoietin-1, a proangiogenic factor, were recently shown to be increased in the serum of infants with severe BPD and $\mathrm{PH}$ compared to those with severe $\mathrm{BPD}$ without $\mathrm{PH}$ and those with no or mild BPD [59]. Mice deficient in endothelial NO synthase demonstrate increased susceptibility to experimental BPD, suggesting that VEGF-NO signaling is a key part of the protective response [60].

\section{Intrapulmonary Shunt Vessels in BPD}

Disrupted angiogenesis in BPD not only results in fewer vessels, but some fully developed vessels demonstrate dysmorphic anastomoses. Specifically, intrapulmonary arteriovenous anastomotic vessels have been identified in the lung parenchyma of infants with severe BPD [61]. These shunt vessels, not unlike those seen in alveolar capillary dysplasia, prevent gas exchange from occurring at the alveolar capillary interface [62]. This impairment of gas exchange could result in persistent hypoxemia, hypoxic vasoconstriction of the pulmonary arteries and progression to $\mathrm{PH}$ in the preterm infant [55].

\section{Genetic and Epigenetic Regulation of Impaired Angiogenesis}

Twin studies have suggested that genetic predisposition accounts for a large portion of BPD risk [63, 64]. However, genome-wide association studies have been variably successful $[65,66]$ and unsuccessful [67] in identifying candidate single nucleotide polymorphisms associated with BPD. Polymorphisms in the vitamin D receptor gene were recently shown to be associated with BPD in preterm newborns, supporting preclinical studies in which vitamin $\mathrm{D}$ augments angiogenesis both in vitro and in lipopolysaccharide-induced experimental BPD [68, 69].

Mediated by antenatal gene-environment interactions, epigenetic mechanisms may directly affect vascular development in infants at risk for BPD. Upregulation of the proangiogenic IGF-1 in the lungs of infants with fatal BPD through histone modification after postnatal mechanical ventilation may reflect a response to injury in the pulmonary vasculature [70-72]. Pulmonary histone deacetylase activity is decreased in experimental BPD with resultant upregulation of $\mathrm{p} 21$, a cyclin-dependent kinase that may be proangiogenic $[73,74]$. In both mice and human lung tissues, DNA methylation, another form of epigenetic regulation, has been shown to alter the expression of genes associated with lung development and alveolar septation, including a number of genes in angiogenic pathways [75]. Several studies have also shown that epigenetic regulation by microRNA expression is aberrant in BPD [76, 77]. Transgenic miR-150 knockout mice demonstrate increased angiogenesis when exposed to neonatal hyperoxia, which may be due to the upregulation of glycoprotein nonmetastatic melanoma protein B [78]. The differential regulation of gene expression by these and other mechanisms may explain previous observations that mechanical ventilation and oxygen therapy increase antiangiogenic gene expression (thrombospondin-1, endoglin) and decrease the expression of angiogenic genes (VEGF-B, VEGFR-2, Tie-2) [79, 80].

\section{Endothelial Progenitor Cells and Mesenchymal Stromal Cells in BPD}

In addition to branching angiogenesis, circulating and resident endothelial progenitor cells (EPCs) appear to contribute to postnatal vasculogenesis $[81,82]$. It has been hypothesized that cord blood EPC levels could serve as important clinical biomarkers of BPD risk and indeed 


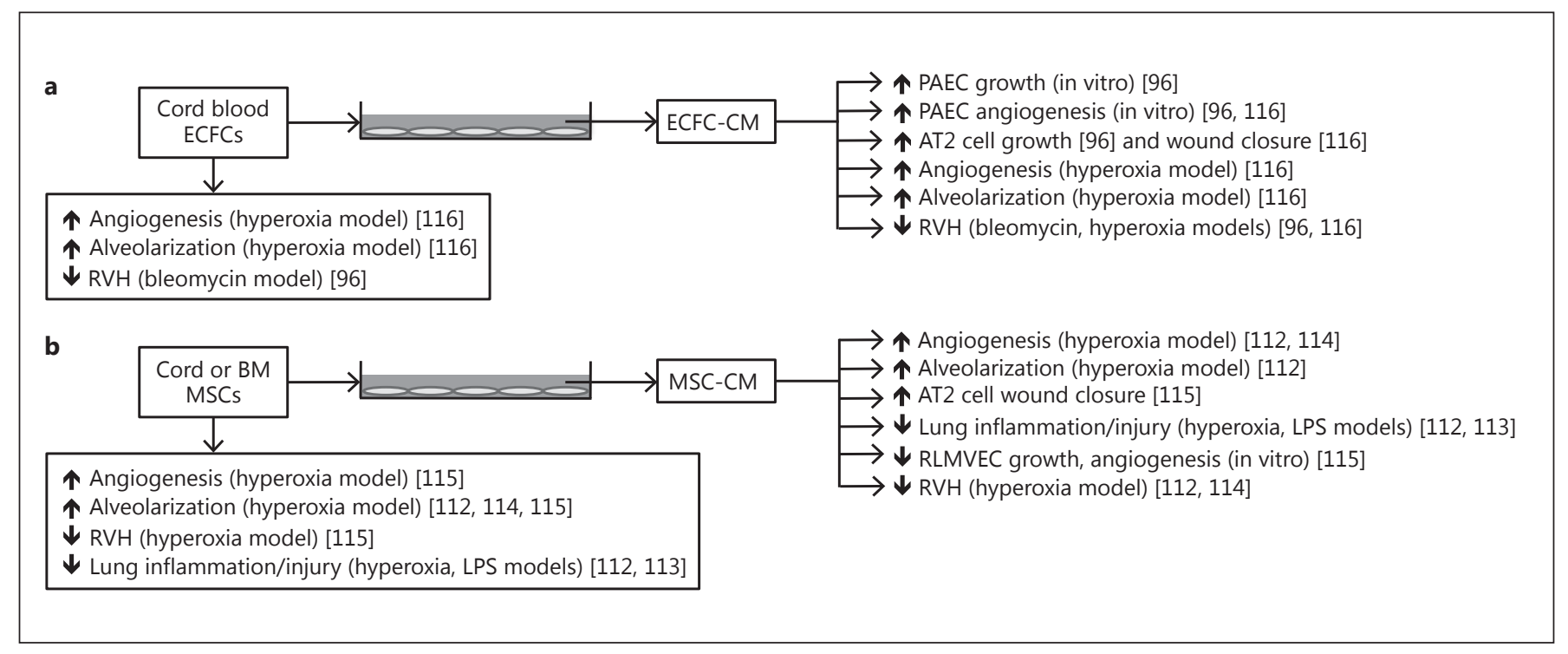

Fig. 1. Paracrine mechanisms mediate the proangiogenic effects of ECFCs and MSCs. PAEC = Pulmonary artery endothelial cell; AT2 = alveolar epithelial type 2 cell; $\mathrm{RVH}=$ right ventricular hypertrophy; $\mathrm{BM}=$ bone marrow; LPS = lipopolysaccharide; RLM$\mathrm{VEC}=$ rat lung microvascular endothelial cell. $\mathrm{CM}$ is collected af-

the umbilical cord blood of infants who later develop moderate or severe BPD is deficient in two differing types of EPCs - late-outgrowth endothelial colony-forming cells (ECFCs) and angiogenic circulating progenitor cells [83-85]. However, other progenitor cell populations, including those first described by flow cytometry analysis as 'triple-positive' EPCs for their expression of CD34, AC133 and VEGFR-2, do not correlate with BPD outcome and cannot be reliably quantified in human cord blood using currently available antibodies [85-87]. CD34+AC133+VEGFR-2+ EPCs are likely to be angiogenic macrophages, which might explain their correlation with adult cardiopulmonary disease [88].

ECFCs are highly proliferative, capable of self-renewal in clonogenic assays and form de novo vessels in vivo [89, 90]. VEGF-NO signaling is impaired in circulating ECFCs isolated from the cord blood of preterm infants [91]. Recently, ECFCs were shown to be decreased in the cord blood of mothers with preeclampsia, suggesting that impaired progenitor cell-mediated vasculogenesis is a mechanism through which the infant is affected by this maternal complication of pregnancy $[92,93]$. ECFCs may also contribute to the development of the placental vasculature and maternal vascular underperfusion in the placenta is associated with BPD risk [94]. Mothers with placental maternal vascular underperfusion were much more likely to

Impaired Pulmonary Vascular

Development in BPD ter $24 \mathrm{~h}$ in culture with either cord blood-derived ECFCs (a) or cord blood/marrow-derived MSCs (b). ECFC-CM and MSC-CM as well as the cells themselves promote angiogenesis both in vitro and in experimental BPD.

have preeclampsia, further strengthening the association between preeclampsia, impaired angiogenesis and BPD in the preterm infant. Highly proliferative endothelial subpopulations reside in vessel walls [82] and may serve as a type of resident vascular progenitor that also contributes to the development of the microvasculature. The paradigm that a circulating EPC homes to a vascular bed to engraft and populate the expanding endothelium, either during development or after vessel injury, has been challenged by studies that fail to show sustained EPC engraftment in the pulmonary vasculature [95] and conditioned media (CM) studies that suggest EPCs may act via paracrine mechanisms to induce local angiogenesis $[96,116]$.

More recently, mesenchymal stromal (stem) cells (MSCs) derived from bone marrow [97, 98], umbilical cord blood [99] or the umbilical cord itself [100, 101] have been considered as potential contributors to BPD pathogenesis and as a promising therapeutic modality [102]. Popova et al. [103] showed that MSCs are increased in tracheal aspirates of preterm infants who go on to develop BPD. Furthermore, airway MSCs isolated from these infants demonstrate autocrine production of TGF- $\beta_{1}$ that promotes their differentiation into a myofibroblast lineage and subsequent fibrotic lung injury [104]. However, bone marrow-derived MSCs do not differentiate into myofibroblasts in the presence of TGF- $\beta_{1}$ activation 
[104], which points to how airway MSCs can be indicative of disease while treatment with MSCs from bone marrow is beneficial [102]. Tracheal MSCs are also deficient in the expression of the proangiogenic platelet-derived growth factor receptor, but this gene expression has not been studied in bone marrow-derived MSCs [105].

\section{Augmentation of Angiogenesis to Treat or Prevent BPD}

A number of prospective clinical trials have studied whether iNO (inhaled NO) therapy can prevent BPD in human preterm infants, with variable [106] to no success [107-109]. However, a recent retrospective analysis of one of these trials suggested that combining iNO with enteral vitamin A supplementation may improve outcomes in certain preterm infants [110]. A prospective randomized clinical trial is now underway to determine whether 28 days of high-dose vitamin A supplementation reduces BPD and death in preterm infants [111].

ECFC and MSC therapy to promote pulmonary vascular growth continues to be studied in both animal models (fig. 1) and early clinical trials. In neonatal mice, MSCs prevent experimental BPD when administered intravenously [112] and intratracheally [113-115]. MSC-CM prevents experimental BPD by these routes as well as when injected into the peritoneal space [112-114]. ECFC and ECFC-CM therapy prevent hyperoxia-induced experimental BPD in newborn rats [116]. ECFC-CM also augments endothelial cell growth and in vitro angiogenesis [96]. A phase 1 clinical trial demonstrated the safety and feasibility of delivering a single intratracheal dose of MSCs to extremely preterm infants at risk for BPD [117].
A phase 2 trial to determine efficacy is in progress. However, questions persist pertaining to the ideal source of stem cell therapy, the ideal timing and route of delivery, the potential for side effects, and whether perinatal complications of pregnancy affect the utility of autologous progenitor cells from the cord or cord blood for therapeutic use $[118,119]$.

\section{Conclusion}

Preterm birth causes impaired vascular and alveolar growth that leads to $\mathrm{BPD}$, the chronic lung disease of infancy. Maternal complications of pregnancy contribute to the risk of preterm birth and BPD by unclear mechanisms, but associations between these complications and impaired angiogenesis have been identified. As noted in a recent workshop of the National Heart Lung and Blood Institute, the primary prevention of BPD in preterm infants has proven elusive [120]. Nevertheless, further studies such as those described in this review will lead to improved outcomes for this devastating neonatal lung disease.

\section{Acknowledgments}

This work was funded by the following sources: NIH K12HL090147-01 and NIH K23-HL121090-01 (to C.D.B.) and NIH R01HL068702 and NIH U01HL102235 (to S.H.A.).

\section{Disclosure Statement}

The authors have no conflicts of interest to disclose.

\section{References}

1 Northway WH, Rosan RC, Porter DY: Pulmonary disease following respirator therapy of hyaline-membrane disease. Bronchopulmonary dysplasia. N Engl J Med 1967;276:357-368.

-2 Chambers HM, van Velzen D: Ventilator-related pathology in the extremely immature lung. Pathology 1989;21:79-83.

- 3 Hislop AA, Haworth SG: Pulmonary vascular damage and the development of cor pulmonale following hyaline membrane disease. Pediatr Pulmonol 1990;9:152-161.

4 Jobe AH: The new BPD: an arrest of lung development. Pediatr Res 1999;46:641-643.

5 Hislop AA: Airway and blood vessel interaction during lung development. J Anat 2002; 201:325-334.
Coalson JJ: Pathology of new bronchopulmonary dysplasia. Semin Neonatol 2003;8:7381.

7 Baker CD, Alvira CM: Disrupted lung development and bronchopulmonary dysplasia: opportunities for lung repair and regeneration. Curr Opin Pediatr 2014;26:306-314.

8 LeBlanc MH, Graves GR, Rawson TW, Moffitt $\mathrm{J}$ : Long-term outcome of infants at the margin of viability. J Miss State Med Assoc 1999;40: 111-114.

-9 Patel RM, Kandefer S, Walsh MC, Bell EF, Carlo WA, Laptook AR, Sanchez PJ, Shankaran S, Van Meurs KP, Ball MB, Hale EC, Newman NS, Das A, Higgins RD, Stoll BJ; Eunice Kennedy Shriver NICHD Neonatal Research Net- work: Causes and timing of death in extremely premature infants from 2000 through 2011. N Engl J Med 2015;372:331-340.

10 Stoll BJ, Hansen NI, Bell EF, Shankaran S, Laptook AR, Walsh MC, Hale EC, Newman NS, Schibler K, Carlo WA, Kennedy KA, Poindexter BB, Finer NN, Ehrenkranz RA, Duara S, Sanchez PJ, O'Shea TM, Goldberg RN, Van Meurs KP, Faix RG, Phelps DL, Frantz ID 3rd, Watterberg KL, Saha S, Das A, Higgins RD: Neonatal outcomes of extremely preterm infants from the NICHD Neonatal Research Network. Pediatrics 2010;126:443-456.

11 Ali Z, Schmidt P, Dodd J, Jeppesen DL: Bronchopulmonary dysplasia: a review. Arch Gynecol Obstet 2013;288:325-333. 
12 Copland I, Post M: Lung development and fetal lung growth. Paediatr Respir Rev 2004;5(suppl A):S259-S264.

13 Coalson JJ: Pathology of chronic lung disease of early infancy; in Bland RD, Coalson JJ (eds): Chronic Lung Disease in Early Infancy. New York, Dekker, 1999, vol 137, pp 85-124.

14 Husain AN, Siddiqui NH, Stocker JT: Pathology of arrested acinar development in postsurfactant bronchopulmonary dysplasia. Hum Pathol 1998;29:710-717.

15 Abman SH: Bronchopulmonary dysplasia: 'a vascular hypothesis'. Am J Respir Crit Care Med 2001;164:1755-1756.

16 Mourani PM, Abman SH: Pulmonary vascular disease in bronchopulmonary dysplasia: pulmonary hypertension and beyond. Curr Opin Pediatr 2013;25:329-337.

17 Bhatt AJ, Amin SB, Chess PR, Watkins RH, Maniscalco WM: Expression of vascular endothelial growth factor and Flk-1 in developing and glucocorticoid-treated mouse lung. Pediatr Res 2000;47:606-613.

-18 Jakkula M, Le Cras TD, Gebb S, Hirth KP, Tuder RM, Voelkel NF, Abman SH: Inhibition of angiogenesis decreases alveolarization in the developing rat lung. Am J Physiol Lung Cell Mol Physiol 2000;279:L600-L607.

-19 Thébaud B, Ladha F, Michelakis ED, Sawicka M, Thurston G, Eaton F, Hashimoto K, Harry G, Haromy A, Korbutt G, Archer SL: Vascular endothelial growth factor gene therapy increases survival, promotes lung angiogenesis, and prevents alveolar damage in hyperoxia-induced lung injury: evidence that angiogenesis participates in alveolarization. Circulation 2005;112:2477-2486.

20 Ding BS, Nolan DJ, Guo P, Babazadeh AO, Cao Z, Rosenwaks Z, Crystal RG, Simons M, Sato TN, Worgall S, Shido K, Rabbany SY, Rafii S: Endothelial-derived angiocrine signals induce and sustain regenerative lung alveolarization. Cell 2011;147:539-553.

-21 Bhatt AJ, Pryhuber GS, Huyck H, Watkins RH, Metlay LA, Maniscalco WM: Disrupted pulmonary vasculature and decreased vascular endothelial growth factor, Flt-1, and TIE-2 in human infants dying with bronchopulmonary dysplasia. Am J Respir Crit Care Med 2001;164: 1971-1980.

22 Flamme I, Risau W: Induction of vasculogenesis and hematopoiesis in vitro. Development 1992;116:435-439.

-23 Risau W: Mechanisms of angiogenesis. Nature 1997;386:671-674.

24 Groenman F, Unger S, Post M: The molecular basis for abnormal human lung development. Biol Neonate 2005;87:164-177.

-25 Narayanan M, Owers-Bradley J, Beardsmore CS, Mada M, Ball I, Garipov R, Panesar KS, Kuehni CE, Spycher BD, Williams SE, Silverman M: Alveolarization continues during childhood and adolescence: new evidence from helium-3 magnetic resonance. Am J Respir Crit Care Med 2012;185:186-191.

26 Hilgendorff A, Reiss I, Ehrhardt H, Eickelberg $\mathrm{O}$, Alvira CM: Chronic lung disease in the preterm infant. Lessons learned from animal models. Am J Respir Cell Mol Biol 2014;50:233-245.
7 Berger J, Bhandari V: Animal models of bronchopulmonary dysplasia. The term mouse models. Am J Physiol Lung Cell Mol Physiol 2014;307:L936-L947.

28 D’Angio CT, Ryan RM: Animal models of bronchopulmonary dysplasia. The preterm and term rabbit models. Am J Physiol Lung Cell Mol Physiol 2014;307:L959-L969.

29 O'Reilly M, Thebaud B: Animal models of bronchopulmonary dysplasia. The term rat models. Am J Physiol Lung Cell Mol Physiol 2014;307:L948-L958.

30 Hellstroem B: The effect of high oxygen concentrations and hypothermia on the lung of the newborn mouse. Acta Paediatr Scand1965;54: 457-466.

31 Warner BB, Stuart LA, Papes RA, Wispe JR: Functional and pathological effects of prolonged hyperoxia in neonatal mice. Am J Physiol 1998;275:L110-L117.

32 Wang H, Jafri A, Martin RJ, Nnanabu J, Farver C, Prakash YS, MacFarlane PM: Severity of neonatal hyperoxia determines structural and functional changes in developing mouse airway. Am J Physiol Lung Cell Mol Physiol 2014; 307:L295-L301.

33 O'Reilly M, Harding R, Sozo F: Altered small airways in aged mice following neonatal exposure to hyperoxic gas. Neonatology 2014;105: 39-45.

34 Choi CW, Kim BI, Hong JS, Kim EK, Kim HS, Choi JH: Bronchopulmonary dysplasia in a rat model induced by intra-amniotic inflammation and postnatal hyperoxia: morphometric aspects. Pediatr Res 2009;65:323-327.

35 Tang J-R, Seedorf GJ, Muehlethaler V, Walker DL, Markham NE, Balasubramaniam V, Abman SH: Moderate postnatal hyperoxia accelerates lung growth and attenuates pulmonary hypertension in infant rats after exposure to intra-amniotic endotoxin. Am J Physiol Lung Cell Mol Physiol 2010;299:L735-L748.

-36 Huang LT, Chou HC, Lin CM, Yeh TF, Chen CM: Maternal nicotine exposure exacerbates neonatal hyperoxia-induced lung fibrosis in rats. Neonatology 2014;106:94-101.

37 Gortner L, Hilgendorff A, Bahner T, Ebsen M, Reiss I, Rudloff S: Hypoxia-induced intrauterine growth retardation: effects on pulmonary development and surfactant protein transcription. Biol Neonate 2005;88:129-135.

38 Monz D, Tutdibi E, Mildau C, Shen J, Kasoha M, Laschke MW, Roolfs T, Schmiedl A, Tschernig T, Bieback K, Gortner L: Human umbilical cord blood mononuclear cells in a double-hit model of bronchopulmonary dysplasia in neonatal mice. PLoS One 2013; 8:e74740.

39 Ratner V, Slinko S, Utkina-Sosunova I, Starkov A, Polin RA, Ten VS: Hypoxic stress exacerbates hyperoxia-induced lung injury in a neonatal mouse model of bronchopulmonary dysplasia. Neonatology 2009;95:299-305.

40 Bland RD, Albertine KH, Carlton DP, MacRitchie AJ: Inhaled nitric oxide effects on lung structure and function in chronically ventilated preterm lambs. Am J Respir Crit Care Med 2005;172:899-906.
41 Lin Y-J, Markham NE, Balasubramaniam V, Tang J-R, Maxey A, Kinsella JP, Abman SH: Inhaled nitric oxide enhances distal lung growth after exposure to hyperoxia in neonatal rats. Pediatr Res 2005;58:22-29.

42 Tang J-R, Markham NE, Lin Y-J, McMurtry IF, Maxey A, Kinsella JP, Abman SH: Inhaled nitric oxide attenuates pulmonary hypertension and improves lung growth in infant rats after neonatal treatment with a VEGF receptor inhibitor. Am J Physiol Lung Cell Mol Physiol 2004;287:L344-L351.

43 Bland RD, Albertine KH, Carlton DP, Kullama L, Davis P, Cho SC, Kim BI, Dahl M, Tabatabaei $\mathrm{N}$ : Chronic lung injury in preterm lambs: abnormalities of the pulmonary circulation and lung fluid balance. Pediatr Res 2000;48: 64-74.

44 Le Cras TD, Markham NE, Tuder RM, Voelkel NF, Abman SH: Treatment of newborn rats with a VEGF receptor inhibitor causes pulmonary hypertension and abnormal lung structure. Am J Physiol Lung Cell Mol Physiol 2002; 283:L555-L562.

-45 Kunig AM, Balasubramaniam V, Markham NE, Morgan D, Montgomery G, Grover TR, Abman SH: Recombinant human VEGF treatment enhances alveolarization after hyperoxic lung injury in neonatal rats. Am J Physiol Lung Cell Mol Physiol 2005;289:L529-L535.

46 Kendall RL, Thomas KA: Inhibition of vascular endothelial cell growth factor activity by an endogenously encoded soluble receptor. Proc Natl Acad Sci USA 1993;90:10705-10709.

- 47 Tang JR, Karumanchi SA, SeedorfG, Markham $\mathrm{N}$, Abman SH: Excess soluble vascular endothelial growth factor receptor-1 in amniotic fluid impairs lung growth in rats: linking preeclampsia with bronchopulmonary dysplasia. Am J Physiol Lung Cell Mol Physiol 2012; 302:L36-L46.

48 Foidart JM, Schaaps JP, Chantraine F, Munaut C, Lorquet S: Dysregulation of anti-angiogenic agents (sFlt-1, PLGF, and sEndoglin) in preeclampsia - a step forward but not the definitive answer. J Reprod Immunol 2009;82:106111.

49 Hansen AR, Barnés CM, Folkman J, McElrath TF: Maternal preeclampsia predicts the development of bronchopulmonary dysplasia. J Pediatr 2010;156:532-536.

50 Levine RJ, Lam C, Qian C, Yu KF, Maynard SE, Sachs BP, Sibai BM, Epstein FH, Romero R, Thadhani R, Karumanchi SA, Group CS: Soluble endoglin and other circulating antiangiogenic factors in preeclampsia. $\mathrm{N}$ Engl J Med 2006;355:992-1005.

-51 Hasan J, Beharry KD, Valencia AM, Strauss A, Modanlou HD: Soluble vascular endothelial growth factor receptor 1 in tracheal aspirate fluid of preterm neonates at birth may be predictive of bronchopulmonary dysplasia/ chronic lung disease. Pediatrics 2009;123: 1541-1547.

52 Voller SB, Chock S, Ernst LM, Su E, Liu X, Farrow KN, Mestan KK: Cord blood biomarkers of vascular endothelial growth (VEGF and sFlt-1) and postnatal growth: a preterm birth cohort study. Early Hum Dev 2014;90:195-200. 
53 Rozance PJ, Seedorf GJ, Brown A, Roe G, O’Meara MC, Gien J, Tang JR, Abman SH: Intrauterine growth restriction decreases pulmonary alveolar and vessel growth and causes pulmonary artery endothelial cell dysfunction in vitro in fetal sheep. Am J Physiol Lung Cell Mol Physiol 2011;301:L860-L871.

-54 Soudee S, Vuillemin L, Alberti C, Mohamed D, Becquet O, Farnoux C, Biran V, Baud O: Fetal growth restriction is worse than extreme prematurity for the developing lung. Neonatology 2014;106:304-310.

55 Baker CD, Abman SH, Mourani PM: Pulmonary hypertension in preterm infants with bronchopulmonary dysplasia. Pediatr Allergy Immunol Pulmonol 2014;27:8-16.

-56 Gien J, Tseng N, Seedorf G, Roe G, Abman SH: Endothelin-1 impairs angiogenesis in vitro through Rho-kinase activation after chronic intrauterine pulmonary hypertension in fetal sheep. Pediatr Res 2013;73:252-262.

-57 Wolf D, Tseng N, Seedorf G, Roe G, Abman SH, Gien J: Endothelin-1 decreases endothelial PPAR $\gamma$ signaling and impairs angiogenesis after chronic intrauterine pulmonary hypertension. Am J Physiol Lung Cell Mol Physiol 2014 306:L361-L371.

58 Morales E, Sakurai R, Husain S, Paek D, Gong M, Ibe B, Li Y, Husain M, Torday JS, Rehan VK: Nebulized PPAR $\gamma$ agonists: a novel approach to augment neonatal lung maturation and injury repair in rats. Pediatr Res 2014;75:631-640.

$>59$ Kim DH, Kim HS: Serial changes of serum endostatin and angiopoietin-1 levels in preterm infants with severe bronchopulmonary dysplasia and subsequent pulmonary artery hypertension. Neonatology 2014;106:55-61.

-60 Balasubramaniam V: Inhaled nitric oxide reverses hypoxia induced lung hypoplasia in endothelial nitric oxide synthase-deficient mice. Chest 2005;128:613S-614S.

61 Galambos C, Sims-Lucas S, Abman SH: Histologic evidence of intrapulmonary anastomoses by three-dimensional reconstruction in severe bronchopulmonary dysplasia. Ann Am Thorac Soc 2013;10:475-481.

62 Galambos C, Sims-Lucas S, Abman SH: Threedimensional reconstruction identifies misaligned pulmonary veins as intrapulmonary shunt vessels in alveolar capillary dysplasia. J Pediatr 2014;164:192-195.

-63 Bhandari V, Bizzarro MJ, Shetty A, Zhong X, Page GP, Zhang H, Ment LR, Gruen JR: Familial and genetic susceptibility to major neonatal morbidities in preterm twins. Pediatrics 2006 117:1901-1906.

64 Lavoie PM, Pham C, Jang KL: Heritability of bronchopulmonary dysplasia, defined according to the consensus statement of the national institutes of health. Pediatrics 2008;122:479485.

-65 Hadchouel A, Durrmeyer X, Bouzigon E, Incitti R, Huusko J, Jarreau PH, Lenclen R, Demenais F, Franco-Montoya ML, Layouni I, Patkai J, Bourbon J, Hallman M, Danan C, Delacourt C: Identification of SPOCK2 as a susceptibility gene for bronchopulmonary dysplasia. Am J Respir Crit Care Med 2011;184: 1164-1170.
66 Ambalavanan N, Cotten CM, Page GP, Carlo WA, Murray JC, Bhattacharya S, Mariani TJ, Cuna AC, Faye-Petersen OM, Kelly D, Higgins RD; Genomics, Cytokine Subcommittees of the Eunice Kennedy Shriver NICHD Neonatal Research Network: Integrated genomic analyses in bronchopulmonary dysplasia. J Pediatr 2015;166:531-537.

67 Wang H, St Julien KR, Stevenson DK, Hoffmann TJ, Witte JS, Lazzeroni LC, Krasnow MA, Quaintance CC, Oehlert JW, Jelliffe-Pawlowski LL, Gould JB, Shaw GM, O’Brodovich HM: A genome-wide association study (GWAS) for bronchopulmonary dysplasia. Pediatrics 2013;132:290-297.

68 Koroglu OA, Onay H, Cakmak B, Bilgin B, Yalaz M, Tunc S, Ozkinay F, Kultursay N: Association of vitamin $\mathrm{D}$ receptor gene polymorphisms and bronchopulmonary dysplasia. Pediatr Res 2014;76:171-176.

69 Mandell E, Seedorf G, Gien J, Abman SH: Vi tamin $\mathrm{D}$ treatment improves survival and infant lung structure after intra-amniotic endotoxin exposure in rats: potential role for the prevention of bronchopulmonary dysplasia. Am J Physiol Lung Cell Mol Physiol 2014; 306:L420-L428.

70 Albertine $\mathrm{KH}$ : Progress in understanding the pathogenesis of BPD using the baboon and sheep models. Semin Perinatol 2013;37:60-68.

71 Chetty A, Andersson S, Lassus P, Nielsen HC: Insulin-like growth factor-1 (IGF-1) and IGF1 receptor (IGF-1r) expression in human lung in RDS and BPD. Pediatr Pulmonol 2004;37: 128-136.

72 Joss-Moore LA, Metcalfe DB, Albertine KH, McKnight RA, Lane RH: Epigenetics and fetal adaptation to perinatal events: diversity through fidelity. J Animal Sci 2010;88:E216E222.

73 Londhe VA, Sundar IK, Lopez B, Maisonet TM, Yu Y, Aghai ZH, Rahman I: Hyperoxia impairs alveolar formation and induces senescence through decreased histone deacetylase activity and up-regulation of p21 in neonatal mouse lung. Pediatr Res 2011;69:371-377.

74 Kuljaca S, Liu T, Dwarte T, Kavallaris M, Haber M, Norris MD, Martin-Caballero J, Marshall GM: The cyclin-dependent kinase inhibitor, p21(WAF1), promotes angiogenesis by repressing gene transcription of thioredoxin-binding protein 2 in cancer cells. Carcinogenesis 2009;30:1865-1871.

75 Cuna A, Halloran B, Faye-Petersen O, Kelly D, Crossman DK, Cui X, Pandit K, Kaminski N, Bhattacharya S, Ahmad A, Mariani TJ, Ambalavanan $\mathrm{N}$ : Alterations in gene expression and DNA methylation during murine and human lung alveolar septation. Am J Respir Cell Mol Biol 2014, Epub ahead of print.

76 Wu YT, Chen WJ, Hsieh WS, Tsao PN, Yu SL, Lai CY, Lee WC, Jeng SF: MicroRNA expression aberration associated with bronchopulmonary dysplasia in preterm infants: a preliminary study. Respir Care 2013;58:1527-1535.
77 Yang Y, Qiu J, Kan Q, Zhou XG, Zhou XY: MicroRNA expression profiling studies on bronchopulmonary dysplasia: a systematic review and meta-analysis. Genet Mol Res 2013;12: 5195-5206.

78 Narasaraju T, Shukla D, More S, Huang C, Zhang L, Xiao X, Liu L: Role of microRNA-150 and glycoprotein nonmetastatic melanoma protein B in angiogenesis during hyperoxiainduced neonatal lung injury. Am J Respir Cell Mol Biol 2015;52:253-261.

79 De Paepe ME, Greco D, Mao Q: Angiogenesisrelated gene expression profiling in ventilated preterm human lungs. Exp Lung Res 2010;36: 399-410.

80 De Paepe ME, Patel C, Tsai A, Gundavarapu S, Mao Q: Endoglin (CD105) up-regulation in pulmonary microvasculature of ventilated preterm infants. Am J Respir Crit Care Med 2008; 178:180-187.

81 Asahara T, Murohara T, Sullivan A, Silver M, van der Zee R, Li T, Witzenbichler B, Schatteman $\mathrm{G}$, Isner JM: Isolation of putative progenitor endothelial cells for angiogenesis. Science 1997;275:964-967.

-82 Ingram DA, Mead LE, Moore DB, Woodard W, Fenoglio A, Yoder MC: Vessel wall-derived endothelial cells rapidly proliferate because they contain a complete hierarchy of endothelial progenitor cells. Blood 2005;105:27832786.

83 Baker CD, Balasubramaniam V, Mourani PM, Sontag MK, Black CP, Ryan SL, Abman SH: Cord blood angiogenic progenitor cells are decreased in bronchopulmonary dysplasia. Eur Respir J 2012;40:1516-1522.

84 Borghesi A, Massa M, Campanelli R, Bollani L, Tzialla C, Figar TA, Ferrari G, Bonetti E, Chiesa G, De Silvestri A, Spinillo A, Rosti V, Stronati $\mathrm{M}$ : Circulating endothelial progenitor cells in preterm infants with bronchopulmonary dysplasia. Am J Respir Crit Care Med 2009; 180:540-546.

85 Estes ML, Mund JA, Ingram DA, Case J: Identification of endothelial cells and progenitor cell subsets in human peripheral blood. Curr Protoc Cytom 2010;9(unit 9.33):1-11.

$>86$ Baker CD, Ryan SL, Ingram DA, Seedorf GJ, Abman SH, Balasubramaniam V: Endothelial colony-forming cells from preterm infants are increased and more susceptible to hyperoxia. Am J Respir Crit Care Med 2009;180:454-461.

-87 Borghesi A, Massa M, Campanelli R, Garofoli F, Longo S, Cabano R, Mazzucchelli I, Tzialla C, Gavilanes AW, Gazzolo D, Manzoni P, Bollani L, Spinillo A, Rosti V, Stronati M: Different subsets of circulating angiogenic cells do not predict bronchopulmonary dysplasia or other diseases of prematurity in preterm infants. Int J Immunopathol Pharmacol 2013;26: 809-816

88 Case J, Mead LE, Bessler WK, Prater D, White HA, Saadatzadeh MR, Bhavsar JR, Yoder MC, Haneline LS, Ingram DA: Human CD34+AC133+VEGFR-2+ cells are not endothelial progenitor cells but distinct, primitive hematopoietic progenitors. Exp Hematol 2007;35:1109-1118. 
89 Ingram DA, Mead LE, Tanaka H, Meade V, Fenoglio A, Mortell K, Pollok K, Ferkowicz MJ, Gilley D, Yoder MC: Identification of a novel hierarchy of endothelial progenitor cells using human peripheral and umbilical cord blood. Blood 2004;104:2752-2760.

90 Ingram DA, Krier TR, Mead LE, Mcguire C, Prater DN, Bhavsar J, Saadatzadeh MR, Bijangi-Vishehsaraei K, Li F, Yoder MC, Haneline LS: Clonogenic endothelial progenitor cells are sensitive to oxidative stress. Stem Cells 2007;25:297-304.

-91 Fujinaga H, Baker CD, Ryan SL, Markham NE, Seedorf GJ, Balasubramaniam V, Abman SH: Hyperoxia disrupts vascular endothelial growth factor-nitric oxide signaling and decreases growth of endothelial colony-forming cells from preterm infants. Am J Physiol Lung Cell Mol Physiol 2009;297:L1160-L1169.

92 Munoz-Hernandez R, Miranda ML, Stiefel P, Lin RZ, Praena-Fernandez JM, DominguezSimeon MJ, Villar J, Moreno-Luna R, MeleroMartin JM: Decreased level of cord blood circulating endothelial colony-forming cells in preeclampsia. Hypertension 2014;64:165-171.

-93 von Versen-Hoynck F, Brodowski L, Dechend R, Myerski AC, Hubel CA: Vitamin D antagonizes negative effects of preeclampsia on fetal endothelial colony forming cell number and function. PLoS One 2014;9:e98990.

-94 Mestan KK, Check J, Minturn L, Yallapragada S, Farrow KN, Liu X, Su E, Porta N, Gotteiner N, Ernst LM: Placental pathologic changes of maternal vascular underperfusion in bronchopulmonary dysplasia and pulmonary hypertension. Placenta 2014;35:570-574.

$\$ 5$ Ohle SJ, Anandaiah A, Fabian AJ, Fine A, Kotton DN: Maintenance and repair of the lung endothelium does not involve contributions from marrow-derived endothelial precursor cells. Am J Respir Cell Mol Biol 2012; 47:11-19.

-96 Baker CD, Seedorf GJ, Wisniewski BL, Black CP, Ryan SL, Balasubramaniam V, Abman SH: Endothelial colony-forming cell conditioned media promote angiogenesis in vitro and prevent pulmonary hypertension in experimental bronchopulmonary dysplasia. Am J Physiol Lung Cell Mol Physiol 2013; 305:L73-L81.

97 Prockop DJ: Marrow stromal cells as stem cells for nonhematopoietic tissues. Science 1997;276:71-74.

\$8 Jiang Y, Jahagirdar BN, Reinhardt RL, Schwartz RE, Keene CD, Ortiz-Gonzalez XR, Reyes M, Lenvik T, Lund T, Blackstad M, Du J, Aldrich S, Lisberg A, Low WC, Largaespada DA, Verfaillie CM: Pluripotency of mesenchymal stem cells derived from adult marrow. Nature 2002;418:41-49.

-99 Erices A, Conget P, Minguell JJ: Mesenchymal progenitor cells in human umbilical cord blood. Br J Haematol 2000; 109:235-242.

100 Baksh D, Yao R, Tuan RS: Comparison of proliferative and multilineage differentiation potential of human mesenchymal stem cells derived from umbilical cord and bone marrow. Stem Cells 2007;25:1384-1392.
01 Wang HS, Hung SC, Peng ST, Huang CC, Wei HM, Guo YJ, Fu YS, Lai MC, Chen CC: Mesenchymal stem cells in the Wharton's jelly of the human umbilical cord. Stem Cells 2004;22:1330-1337.

102 Pierro M, Thébaud B: Mesenchymal stem cells in chronic lung disease: culprit or savior? Am J Physiol Lung Cell Mol Physiol 2010; 298:L732-L734.

103 Popova AP, Bozyk PD, Bentley JK, Linn MJ, Goldsmith AM, Schumacher RE, Weiner GM, Filbrun AG, Hershenson MB: Isolation of tracheal aspirate mesenchymal stromal cells predicts bronchopulmonary dysplasia. Pediatrics 2010;126:e1127-e1133.

104 Popova AP, Bozyk PD, Goldsmith AM, Linn MJ, Lei J, Bentley JK, Hershenson MB: Autocrine production of TGF- $\beta 1$ promotes myofibroblastic differentiation of neonatal lung mesenchymal stem cells. Am J Physiol Lung Cell Mol Physiol 2010;298:L735-L743.

105 Popova AP, Bentley JK, Cui TX, Richardson MN, Linn MJ, Lei J, Chen Q, Goldsmith AM, Pryhuber GS, Hershenson MB: Reduced platelet-derived growth factor receptor expression is a primary feature of human bronchopulmonary dysplasia. Am J Physiol Lung Cell Mol Physiol 2014;307:L231-L239.

106 Kinsella JP, Cutter GR, Walsh WF, Gerstmann DR, Bose CL, Hart C, Sekar KC, Auten RL, Bhutani VK, Gerdes JS, George TN, Southgate WM, Carriedo H, Couser RJ, Mammel MC, Hall DC, Pappagallo M, Sardesai S, Strain JD, Baier M, Abman SH: Early inhaled nitric oxide therapy in premature newborns with respiratory failure. $\mathrm{N}$ Engl J Med 2006;355:354-364.

107 Askie LM, Ballard RA, Cutter GR, Dani C, Elbourne D, Field D, Hascoet JM, Hibbs AM, Kinsella JP, Mercier JC, Rich W, Schreiber MD, Wongsiridej PS, Subhedar NV, Van Meurs KP, Voysey M, Barrington K, Ehrenkranz RA, Finer NN; Meta-analysis of Preterm Patients on Inhaled Nitric Oxide Collaboration: Inhaled nitric oxide in preterm infants: an individual-patient data metaanalysis of randomized trials. Pediatrics 2011; 128:729-739.

108 Ballard RA, Truog WE, Cnaan A, Martin RJ, Ballard PL, Merrill JD, Walsh MC, Durand DJ, Mayock DE, Eichenwald EC, Null DR, Hudak ML, Puri AR, Golombek SG, Courtney SE, Stewart DL, Welty SE, Phibbs RH, Hibbs AM, Luan X, Wadlinger SR, Asselin JM, Coburn CE; NO CLD Group: Inhaled nitric oxide in preterm infants undergoing mechanical ventilation. N Engl J Med 2006;355: 343-353.

109 Kinsella JP, Cutter GR, Steinhorn RH, Nelin LD, Walsh WF, Finer NN, Abman SH: Noninvasive inhaled nitric oxide does not prevent bronchopulmonary dysplasia in premature newborns. J Pediatr 2014;165:1104-1108.

110 Gadhia MM, Cutter GR, Abman SH, Kinsella JP: Effects of early inhaled nitric oxide therapy and vitamin a supplementation on the risk for bronchopulmonary dysplasia in premature newborns with respiratory failure. J Pediatr 2014;164:744-748.
111 Meyer S, Gortner L, NeoVita ATI: Early postnatal additional high-dose oral vitamin A supplementation versus placebo for 28 days for preventing bronchopulmonary dysplasia or death in extremely low birth weight infants. Neonatology 2014;105:182-188.

112 Aslam M, Baveja R, Liang OD, FernandezGonzalez A, Lee C, Mitsialis SA, Kourembanas S: Bone marrow stromal cells attenuate lung injury in a murine model of neonatal chronic lung disease. Am J Respir Crit Care Med 2009;180:1122-1130.

113 Ionescu L, Byrne RN, van Haaften T, Vadivel A, Alphonse RS, Rey-Parra GJ, Weissmann G, Hall A, Eaton F, Thebaud B: Stem cell conditioned medium improves acute lung injury in mice: in vivo evidence for stem cell paracrine action. Am J Physiol Lung Cell Mol Physiol 2012;303:L967-L977.

-114 Pierro M, Ionescu L, Montemurro T, Vadivel A, Weissmann G, Oudit G, Emery D, Bodiga S, Eaton F, Peault B, Mosca F, Lazzari L, Thebaud B: Short-term, long-term and paracrine effect of human umbilical cord-derived stem cells in lung injury prevention and repair in experimental bronchopulmonary dysplasia. Thorax 2013;68:475-484.

-115 Van Haaften T, Byrne R, Bonnet S, Rochefort GY, Akabutu J, Bouchentouf M, Rey-Parra GJ, Galipeau J, Haromy A, Eaton F, Chen M, Hashimoto K, Abley D, Korbutt G, Archer SL, Thebaud B: Airway delivery of mesenchymal stem cells prevents arrested alveolar growth in neonatal lung injury in rats. Am J Respir Crit Care Med 2009:180:1131-1142.

116 Alphonse RS, Vadivel A, Fung M, Shelley WC, Critser PJ, Ionescu L, O’Reilly M, Ohls RK, McConaghy S, Eaton F, Zhong S, Yoder $\mathrm{M}$, Thebaud B: Existence, functional impairment, and lung repair potential of endothelial colony-forming cells in oxygen-induced arrested alveolar growth. Circulation 2014;129: 2144-2157.

117 Chang YS, Ahn SY, Yoo HS, Sung SI, Choi SJ, Oh WI, Park WS: Mesenchymal stem cells for bronchopulmonary dysplasia: phase 1 doseescalation clinical trial. J Pediatr 2014;164: 966-972.

118 Baker CD, Abman SH: Umbilical cord stem cell therapy for bronchopulmonary dysplasia: ready for prime time? Thorax 2013;68:402404.

119 Kourembanas S: Stem cell-based therapy for newborn lung and brain injury: feasible, safe, and the next therapeutic breakthrough? J Pediatr 2014;164:954-956.

- 120 McEvoy CT, Jain L, Schmidt B, Abman S, Bancalari E, Aschner JL: Bronchopulmonary dysplasia: NHLBI workshop on the primary prevention of chronic lung diseases. Ann Am Thorac Soc 2014;11(suppl 3):S146-S153.

-121 Cuevas Guaman M, Gien J, Baker CD, Zhang H, Austin ED, Collaco JM: Point prevalence, clinical characteristics, and treatment variation for infants with severe bronchopulmonary dysplasia. Am J Perinatol 2015, DOI:10.1055/s-0035-1547326. 